\title{
Waste foundry sand characterization as paving
}

\section{aggregate}

\section{Caracterização de areia descartada de fundição como agregado para pavimentação}

\author{
Paulo Paiva Dyer ${ }^{1}$, Silvelene Alessandra Silva ${ }^{2}$, Luis Miguel Gutierrez Klinsky ${ }^{3}$, \\ Gustavo Lauer Coppio ${ }^{4}$, Maryangela Geimba de Lima ${ }^{5}$ \\ ${ }^{1}$ Instituto Tecnológico de Aeronáutica, Brasil, paulo_dyer@yahoo.com \\ 2Instituto de Estudos Avançados, Brasil, lenisoni@uol.com.br \\ ${ }^{3}$ Consórcio Grupo CCR Nova Dutra, Brasil, luis.gutierrez@grupoccr.com.br \\ ${ }^{4}$ Instituto Federal de Educação, Ciência e Tecnologia de São Paulo, São Paulo - Brasil, gustavocoppio@gmail.com \\ 5Instituto Tecnológico de Aeronáutica, Brasil, magdlima@ita.br
}

\section{Recebido:}

3 de dezembro de 2019

Aceito para publicação:

28 de fevereiro de 2020

Publicado:

30 de abril de 2021

Editor de área:

Francisco Thiago Aragão

\section{Keywords:}

Asphalt paving.

Discarded foundry sand.

Sustainability in construction.

Reuse.

\section{Palavras-chave:}

Areia descartada de fundição.

Pavimentação asfáltica.

Sustentabilidade na construção.

Reuso.

DOI:10.14295/transportes.v29.11.2241

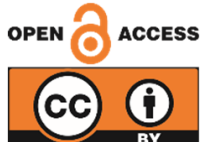

\begin{abstract}
Waste Foundry Sands (WFS) are by-products of the steel industry due to the foundry process. The residual material can be used in civil construction as an aggregate because of its mineral origin. This paper aimed to characterize the WFS obtained at two sources, using laboratory tests that are regularly required in highway engineering specifications. The laboratory program showed that the tests results satisfy the main specifications in Brazil. Laboratory tests results also show that WFS has characteristics that are similar to the manufactured sand that is usually used in asphalt pavement construction. It is concluded that the WFS could be used in asphalt pavement projects, as a subgrade reinforcement, sub-base or base layer and in asphalt wearing courses.
\end{abstract}

\section{RESUMO}

As Areias Descartadas de Fundição (ADFs) são subprodutos das indústrias siderúrgicas devido ao processo de fundição. Este material residual pode ser utilizado na construção civil como um agregado devido à sua origem mineral. $O$ presente trabalho objetivou a caracterização da ADF obtida em duas fontes, por meio de ensaios laboratoriais empregados usualmente pelas especificações da engenharia rodoviária. Os resultados obtidos neste programa laboratorial mostraram resultados que atendem às principais especificações brasileiras. Os resultados laboratoriais também indicam similitude da ADF com o pó de pedra de origem mineral usualmente empregado na construção de pavimentos asfálticos. Conclui-se que a ADF poderia ser empregada em projetos de pavimentação asfáltica, seja em camadas de reforço de subleito, sub-base, base ou misturas asfálticas na camada de revestimento.

\section{INTRODUCTION}

In Brazil, the foundry industry has a huge economic importance since it is responsible of the metal parts production, supplying several industrial chains. According to the annual report of the Associação Brasileira de Fundição (ABIFA) until Dec/2019 over 2,1 million tons of casting parts were produced in Brazil, generating over 1 million tons of Waste Foundry Sand (WFS).

This large volume raises some concern about the lifespan of industrial landfills or environmental contamination. However, the reuse of WFS in civil construction activities has proven to 
be technically viable according to recent studies (Mishra, 2015; Klinsky et al., 2015; YazoghliMarzouk et al., 2014; Abdulsattar, 2018) since, the construction market, particularly asphalt paving projects, are the major consumers of mineral aggregates. In addition, this sector is also a strong indicator of socioeconomic growth, consequently new development should be released in the future, which might exhaust natural resources if alternative materials are not used in construction. Thus, the reuse of WFS in asphalt paving works is an alternative to bring sustainability to the construction market and to give a destination to an industrial by-product produced in large quantities. Nevertheless, careful research is needed to characterize it according to road engineering standards to ensure that the residue does not compromise the safety of the infrastructure

\section{LITERATURE REVIEW}

The sustainability in civil construction has as its main objective to integrate the concepts of social and environmental education into construction, occupation and post-construction phases of projects using new technologies without compromising design and comfort, according to Cavalcanti et al. (1994). In this model, we are concerned about the efficiency and the environmental impact reduction of an edification (Cavalcanti et al., 1994).

In a similar way to the construction market, the foundry industry faces sustainable development problems because it is a market segment of great economic importance, responsible for the production of metal parts used in various industrial chains, especially the automotive, in Brazil and worldwide. This intense industrial productivity generates a large amount of waste. According to ABIFA (ABIFA, 2019), this productivity is around 2 million tons of casting produced in Brazil per year.

The foundry process uses mineral sand as a mold for metal parts. This industrial process can be summarized as follows: firstly, a prototype part previously manufactured is positioned in a containment box; secondly, the voids between the prototype parts and the containment box are filled with saturated sand with binders (water, fatty acids, mineral oils, etc.) and the set is vibrated; then, the prototype part is removed; the molten metal is poured into this space; the set cools down; finally the mold is broken, and the metal part is obtained, as illustrated in Figure 1.

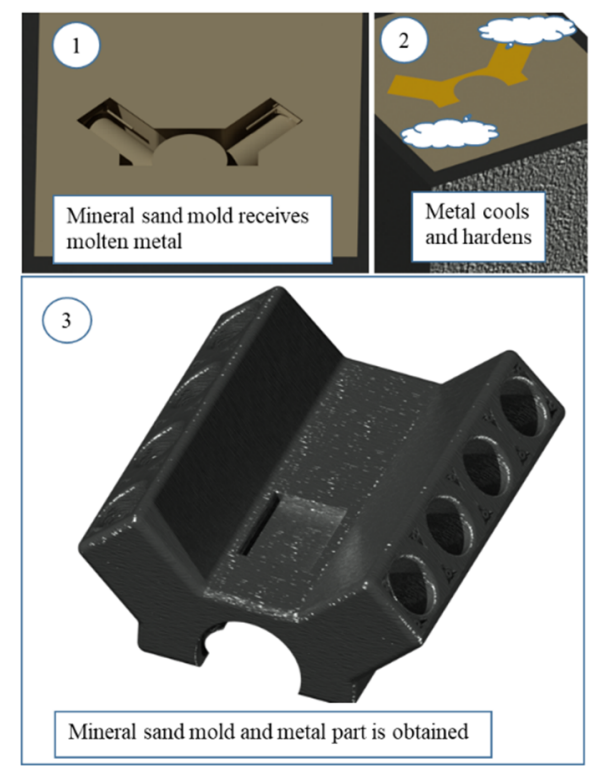

Figure 1. Simplified casting process 
The casting processes are classified according to the type of binder which can be hydrophobic or hydrophilic materials. According to Adegas (2007) they are:

- Green sand: mineral sands molded in the shape of the mold in the wet state, that is, saturated with water maintaining the cohesion among the grains;

- Phenolic alkaline: mineral sands molded in the shape of the mold of the part saturated with a phenolic resin and then hot cured with catalyst;

- Urethane phenolic: molded sands saturated with urethane phenolic resins and cold cured with catalyst.

- Furanic: similar to the phenolic alkaline method, but with furanic resin.

- Shell or Shell molding: thermosetting resin, mineral sand and catalyst mixtures are performed. The mixture is placed in the containment box, and then vibrated together with the prototype piece, a shell is formed on its negative surface, the uncured sand is removed and the liquid metal is poured.

- Sodium silicate: the mineral sand is mixed with sodium silicate; then it is compacted in the negative format of the part and the mixture is carbonated with carbon gas.

According to Bonet (2002), the sand can be recovered through a mechanical and thermal treatment after being used. However, after a certain number of reuses this sand is discarded in the average proportion of $600 \mathrm{~kg}$ for each ton of metal parts produced according to Bina (2002). Therefore, a residue that arouses concern because of the volume produced, as illustrated in Figure 2.

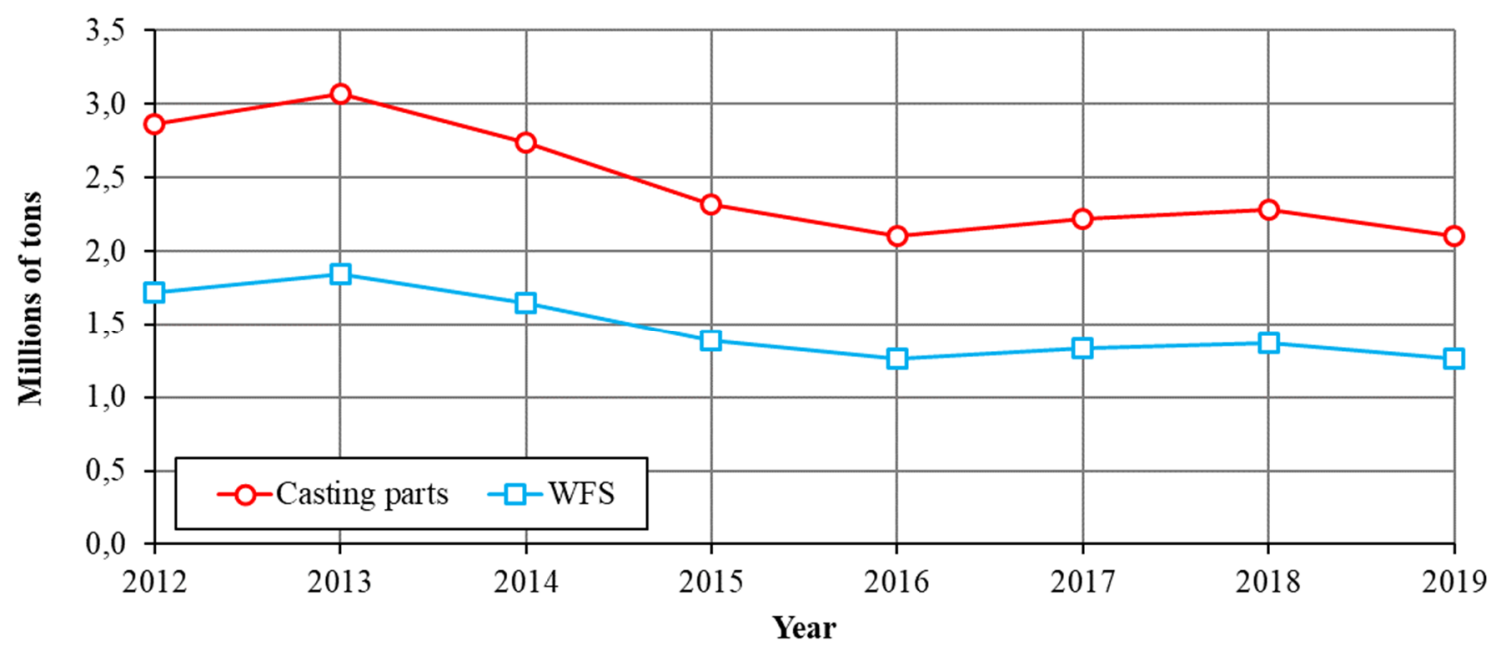

Figure 2. Production of metal castings and WFS over the years in Brazil, ABIFA (2019)

When discarded, this sand is named WFS and is classified as Class II-A or II-B industrial solid waste, i.e., non-hazardous and non-inert: II-A and inert: II-B (CETESB, 2007). However, despite not having acute levels of toxic substances, according to Bonin (2002), WFS should be disposed in landfills, since its frequent disposal increases the concentrations of harmful substances making WFS a potential polluter of soils and water bodies. Grounding is a safe measure; however, it is a costly procedure and dramatically shortens the lifespan of landfills.

Due to the mineral origin of WFS, the reuse of the waste as mineral aggregate has been studied over the years. Table 1 shows the applications that the WFS could have in the civil construction industry according to the Casting Development Centre (TCDC, 1999). 
Table 1 - WFS applications in construction. Adapted from TCDC (1999)

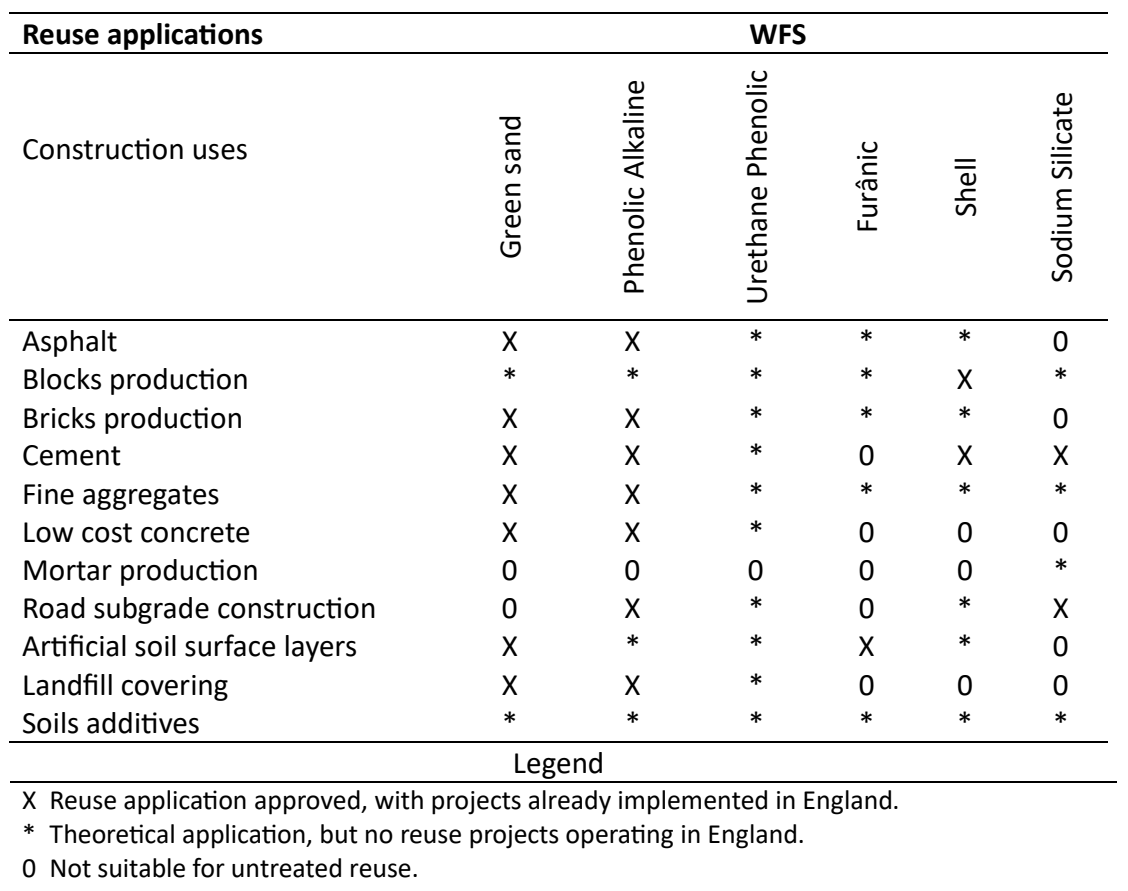

According to Bonet (2002), among the forms of reusing WFS by civil construction, the following uses stand out:

- Supplier of silica: clinker or mineral wool production.

- Fine aggregate: low-cost concrete for non-structural applications and concrete artifacts.

- Fine aggregate: hot mix asphalt mixtures in flexible paving.

- Supplier of minerals: soil adjustment in agriculture.

- Mixtures of soils: subgrade and landfill.

However, the process becomes technically viable for cement manufacturing, only if the generating and consuming sources are close. In relation to other applications, it is verified technologically acceptable results (Bonet, 2002), although there is still a lot of development work to be made, mainly according to current regulations, as the mineral aggregates standard: ABNTNBR: 7211 (2005).

In flexible paving road infrastructure, the reuse of WFS is interesting as it is a large consumer of raw materials and there are projects both nationwide and worldwide. In fact, in the late 1990s, TCDC (TCDC, 1999) promoted, together with the American Foundry Society (AFS, 1999), a set of recommendations for the use of WFS in construction, specifically for asphalt paving projects. This manual motivated new research in this area such as waste application on Hot Mix Asphalt Mixtures HMA: (Coutinho et al., 2004), sand asphalt hot mix SAHM: (Klinsky et al., 2012), base and subbase courses: (Yazoghli-Marzouk et al., 2014; Klinsky et al., 2015) and subgrade reinforcement course: (Klinsky et al., 2014; Sharma et al., 2013); these results showed its technical viability. Other studies showed that the residue remains encapsulated in the asphalt matrix, making it environmentally safe (Bina, 2002; Dyer et al., 2018). Thus, the reuse of WFS have potential but tests are still necessary to classify it according to the road engineering standards. 


\section{MATERIALS AND METHODS}

\subsection{Materials}

\subsubsection{Waste foundry sand}

WFSs from two different sources were used in this paper. One of the residues, herein named WFS-1, comes from an industrial waste landfill, and was grounded under a layer of 3 meters of soil for approximately 30 years; the second, here named WFS-2, comes directly from the steel industry that produces iron and aluminum parts and dispose this waste in this same landfill located in the city of São José dos Campos/Brazil.

\subsubsection{Manufactured sand}

The manufactured sand was collected in a quarry located in the city of Jambeiro/Brazil. This mineral aggregate, originated from milled and detonation of rocks, is widely used in paving projects and has been tested in this paper in comparison to WFS.

\subsubsection{Reagents}

In the sand equivalent test, a "concentrated solution" was prepared containing $57 \mathrm{~g}$ anhydrous calcium chloride (technical grade), 2,6 kg bi-distilled glycerin (USP grade), 57,5 g formaldehyde ( $40 \%$ by volume) and distilled water to complete a volume of 5 liters. The "working solution" was prepared using $125 \mathrm{~cm}^{3}$ of the concentrated solution diluted with distilled water to a volume of 5 liters.

\subsection{Methods}

\subsubsection{WFS collection and Sampling}

To collect the WFS from the embankment a random site was selected and the first 4.5 meters were removed and discarded. The WFS at this depth, was withdrawal and sifted (passing of 12.7 mm sieve size) forming a $1 \mathrm{~m}^{3}$ pile. Then, samples were obtained according to the NBR 10007 (ABNT, 2004) procedures. A sampler and a scale were used to remove $2 \mathrm{~kg}$ at a time until $50 \mathrm{~kg}$ of WFS-1 were obtained.

In the case of WFS-2, sampling was performed at one of the solid waste collection stations at the industrial landfill. Analogously to the first sampling, a dumpster was chosen. The WFS was withdrawal and sieved forming a $1 \mathrm{~m}^{3}$ pile. Samples were removed from this pile yielding $50 \mathrm{~kg}$ of WFS-2. The Figure 3 illustrates this procedure.

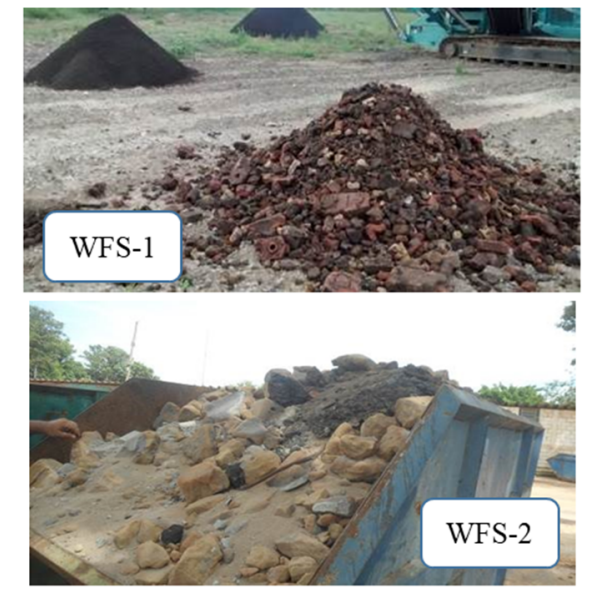

Figure 3. Photographs of WFS sampling process 


\subsubsection{Manufactured sand collection and Sampling}

The manufactured sand was collected at a company that performs the extraction of granite rocks located in the city of Jambeiro/Brazil. In this case, the manufactured sand was sampled in one of the stockpiles. The NBR NM 26 (ABNT, 2001) was followed to obtain a total of $50 \mathrm{~kg}$ of manufactured sand.

\subsubsection{Sample Reduction}

WFS-1 and WFS-2 were reduced to obtain representative samples for each test using the quartering method according to NBR NM 27 (ABNT, 2001a), as illustrated in Figure 4.
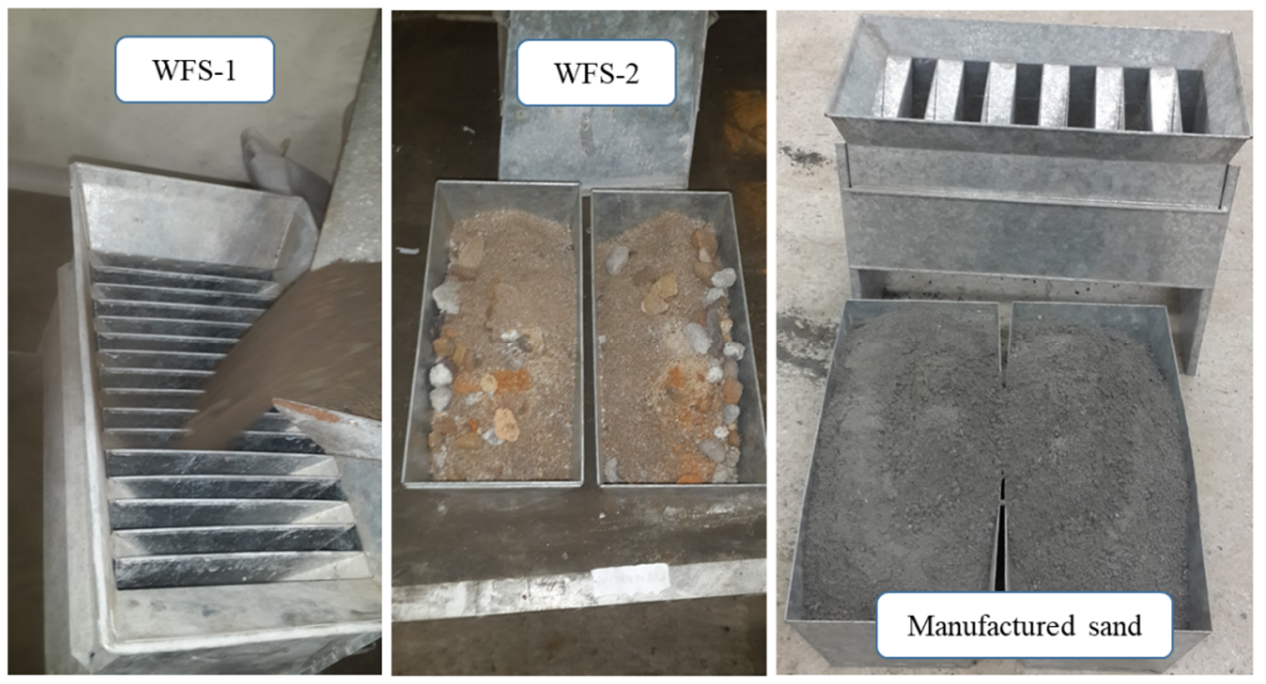

Figure 4. Photographs of sample reduction procedures

\subsubsection{Characterization tests}

The characterization tests are specified in Table 2 and they were performed in the sequence determined by the flowchart of Figure 4.

Table 2 - Methodologies and tests performed

\begin{tabular}{lll}
\hline Materials & Test Method & Denominations \\
\hline & NBR 248 & Particle size composition \\
WFS and manufactured sand & NBR NM 45-C & Unit weight by shoveling \\
& NBR NM 45-A & Unit weight by rodding \\
& AASHTO T-304 & Uncompacted Void Content \\
& NBR NM 46 & Materials finer than 75- $\mu \mathrm{m}$ \\
WFS, manufactured sand and water & NBR NM 52 & Specific gravity \\
& NBR NM 30 & Water absorption \\
WFS, manufactured sand, water and reagents & NBR 6467 & Swelling Determination \\
WFS and manufactured sand & NBR 12052 & Sand Equivalent \\
& ASTM C 123 & Lightweight particles in aggregate \\
\hline
\end{tabular}

The lightweight test was performed as an adaptation of ASTM C 123 (ASTM, 2014). A representative sample of each material was weighed and then these portions were submitted to the temperature of $500{ }^{\circ} \mathrm{C}$ for 30 minutes. After cooling, the samples were weighed again obtaining the percentage of lightweight particles or carbon content in each material. Figure 6 illustrates this procedure. 


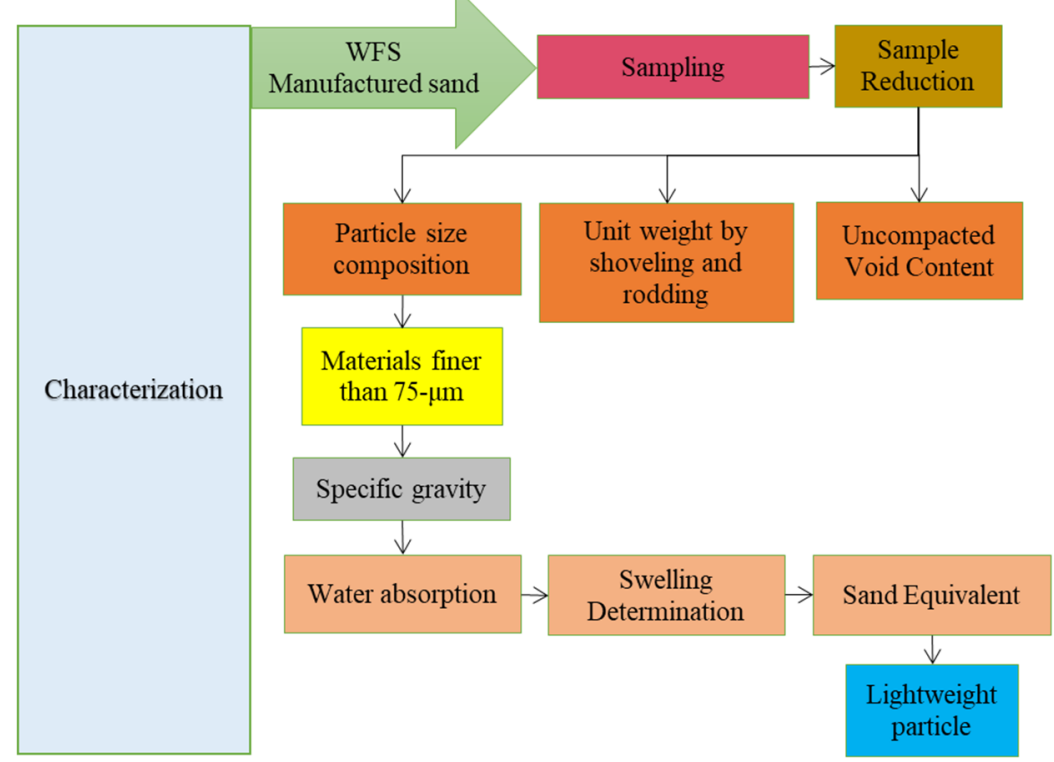

Figure 5. Flowchart of characterization tests

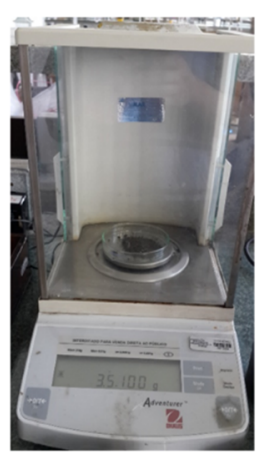

(a)

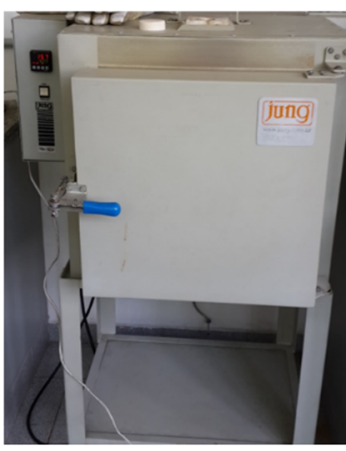

(b)

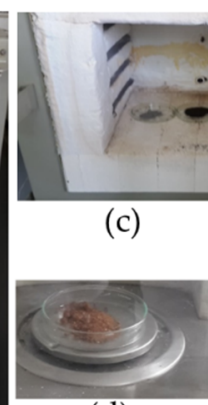

(d)

Figure 6. Illustrative photographs of the Lightweight particles test; (a) initial weighing of samples; (b) $500^{\circ} \mathrm{C}$ for $30 \mathrm{~min}$ in the muffle; (c) samples after heat treatment; (d) WFS-1; (e) WFS-2 and (f) manufactured sand after the test

\section{RESULTS AND DISCUSSION}

The size gradation tests results are presented in Figure 7 and Table 3, including the WFS-1, WFS-2 and manufactured sand.

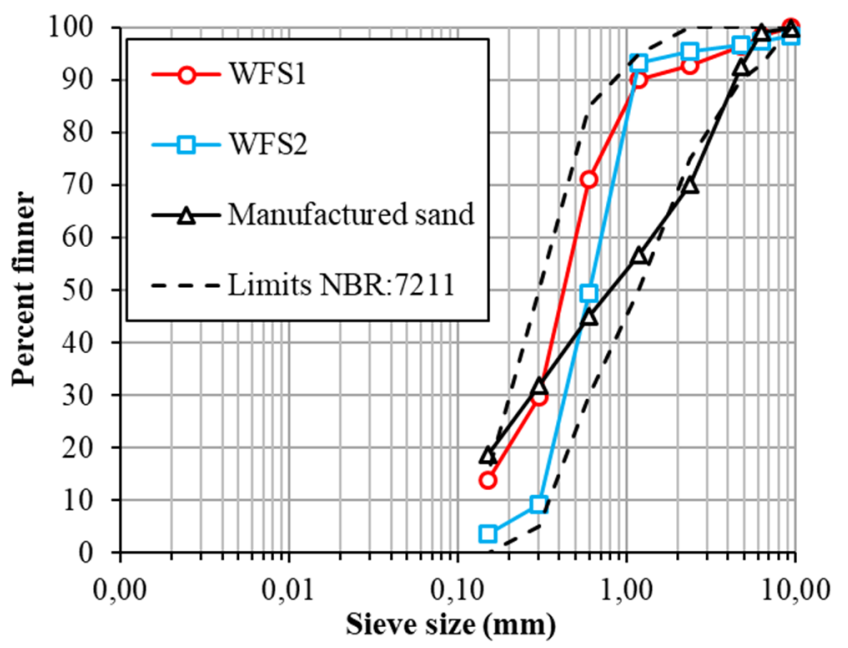

Figure 7. Particle size gradation of WFS and manufactured sand 
Table 3 - Particle size composition of WFS and manufactured sand

\begin{tabular}{llll}
\hline \multirow{2}{*}{ Sieve size $(\mathbf{m m})$} & \multicolumn{2}{c}{ Retained by sieve (\%) } \\
\cline { 2 - 4 } & WFS-1 & WFS-2 & Manufactured sand \\
\hline 9,5 & 0 & 1,5 & 0,1 \\
6,4 & 1,6 & 1,1 & 0,8 \\
4,8 & 1,9 & 0,7 & 6,7 \\
2,4 & 3,6 & 1,2 & 22,4 \\
1,2 & 2,8 & 2,1 & 13,2 \\
0,6 & 19,1 & 43,9 & 11,8 \\
0,3 & 41,2 & 40,2 & 13,1 \\
0,1 & 15,9 & 5,8 & 13,2 \\
\hline Pan: & 13,8 & 3,5 & 18,6 \\
Fineness modulus: & 2,1 & 2,5 & 2,8 \\
Grade: & 2,4 & 2,4 & 2,4 \\
\hline
\end{tabular}

Table 4 shows physical properties of WFS-1, WFS-2 and manufactured sand such as unit weight (by shoveling and rodding method), uncompacted voids, finer than $75-\mu \mathrm{m}$ materials, specific gravity, water absorption, critical humidity, sand equivalent, and carbon content.

Table 4 - Physical characteristics of WFS and manufactured sand

\begin{tabular}{llllll}
\hline \multirow{2}{*}{ Properties } & WFS-1 & WFS-2 & \multirow{2}{*}{ Manufactured sand } & \multicolumn{2}{c}{ Criteria } \\
\cline { 6 - 7 } & & & & Value & Standard \\
\hline Unit weight by shoveling $\left(\mathrm{kg} / \mathrm{dm}^{3}\right)$ & 1429,6 & 1316,1 & 1682,5 & $>1120$ & \multirow{2}{*}{ ASTM C 33 } \\
Unit weight by rodding $\left(\mathrm{kg} / \mathrm{dm}^{3}\right)$ & 1397,5 & 1312,4 & 1651,9 & $>45$ & AASHTO T-304 \\
Uncompacted Void Content $(\%)$ & 46,7 & 53,4 & 45,3 & $<10$ & DNIT ES 031 \\
Materials finer than $75-\mu \mathrm{m}(\%)$ & 6,35 & 3,22 & 13,03 & - & - \\
Real Specific gravity $\left(\mathrm{g} / \mathrm{cm}^{3}\right)$ & 2,7 & 2,6 & 2,4 & - & - \\
Apparent Specific gravity $\left(\mathrm{g} / \mathrm{cm}^{3}\right)$ & 1,9 & 2,1 & 2,3 & $<5$ & ASTM C 33 \\
Water absorption (\%) & 1,6 & 2,5 & 0,6 & - & - \\
Critical humidity (\%) & 7,4 & 5,7 & 6,1 & - & - \\
Average swelling coefficient $\left(\mathrm{T}^{-1}\right)$ & 1,7 & 1,4 & 1,3 & $>55$ & DNIT ES 031 \\
Sand Equivalent (\%) & 37,6 & 49,3 & 32 & - & - \\
Carbon content (\%) & 2,9 & 0,9 & 0,7 & & \\
\hline
\end{tabular}

The swelling curves are shown in Figure 8. Figure 9 illustrates the solutions after the sand equivalent test for WFS and manufactured sand.

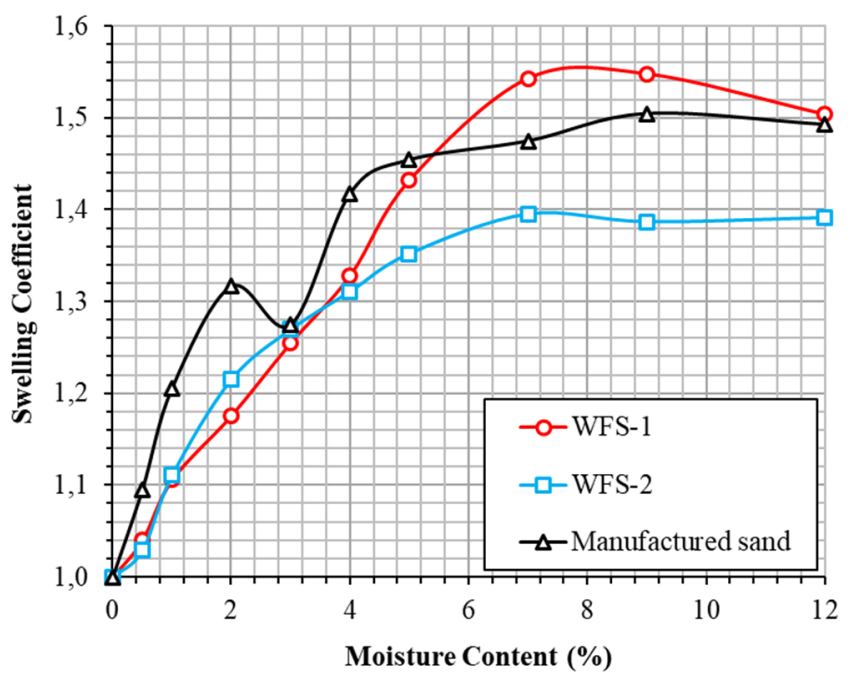

Figure 8. Graph of WFS and manufactured sand swelling curves 


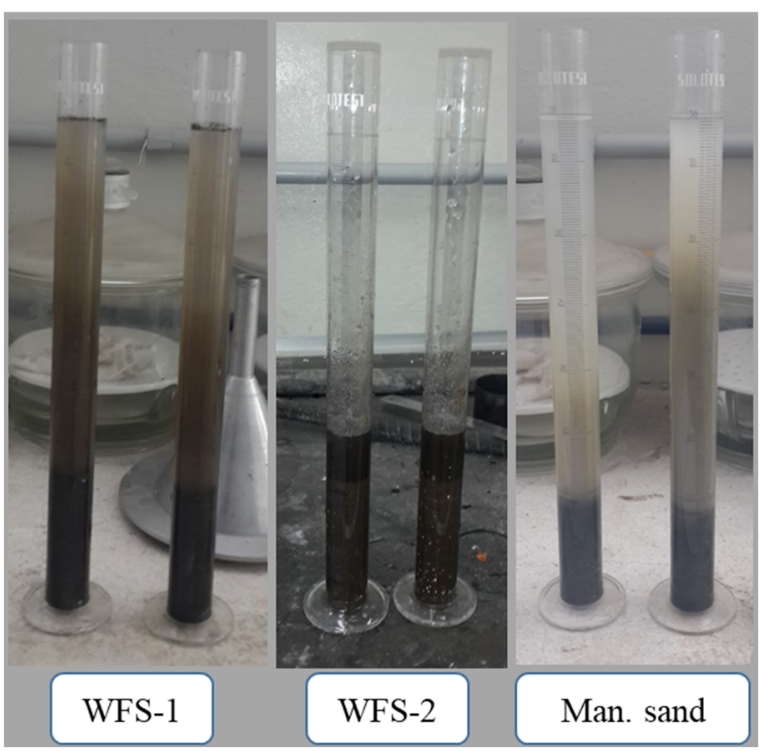

Figure 9. Solutions obtained in sand equivalent test for WFS and manufactured sand

Analyzing the results presented in this paper, it is argued that the WFS has physical properties remarkably similar to manufactured sand and remains within most of the criteria established by the standards. A similarity between the residue and the mineral aggregate is due to the granulometric composition of the WFS classifying it as fine aggregate.

Apparently, the WFS has silt and carbonaceous materials levels above the manufactured sand, which is proven in the lightweight and sand equivalent tests. However, this property does not affect its use in an asphalt pavement structure. In fact, its use in asphalt paving courses can be considered technically viable according to the results found in the literature.

To illustrate the applicability of WFS in asphalt pavement layers, Figure 10 presents the granulometric composition of WFS obtained in this research and compared to other studies. In these studies, the researchers aimed the use of WFS in partial substitutions to conventional materials for applications in subgrade reinforcement course (Sharma et al., 2013; Mishra, 2015), sub-base course (Gedik et al., 2008; Klinsky et al., 2015), base course (Yazoghli-Marzouk et al., 2014; Arulrajah et al., 2017) and HMA (Coutinho, 2004; Costa, 2008).

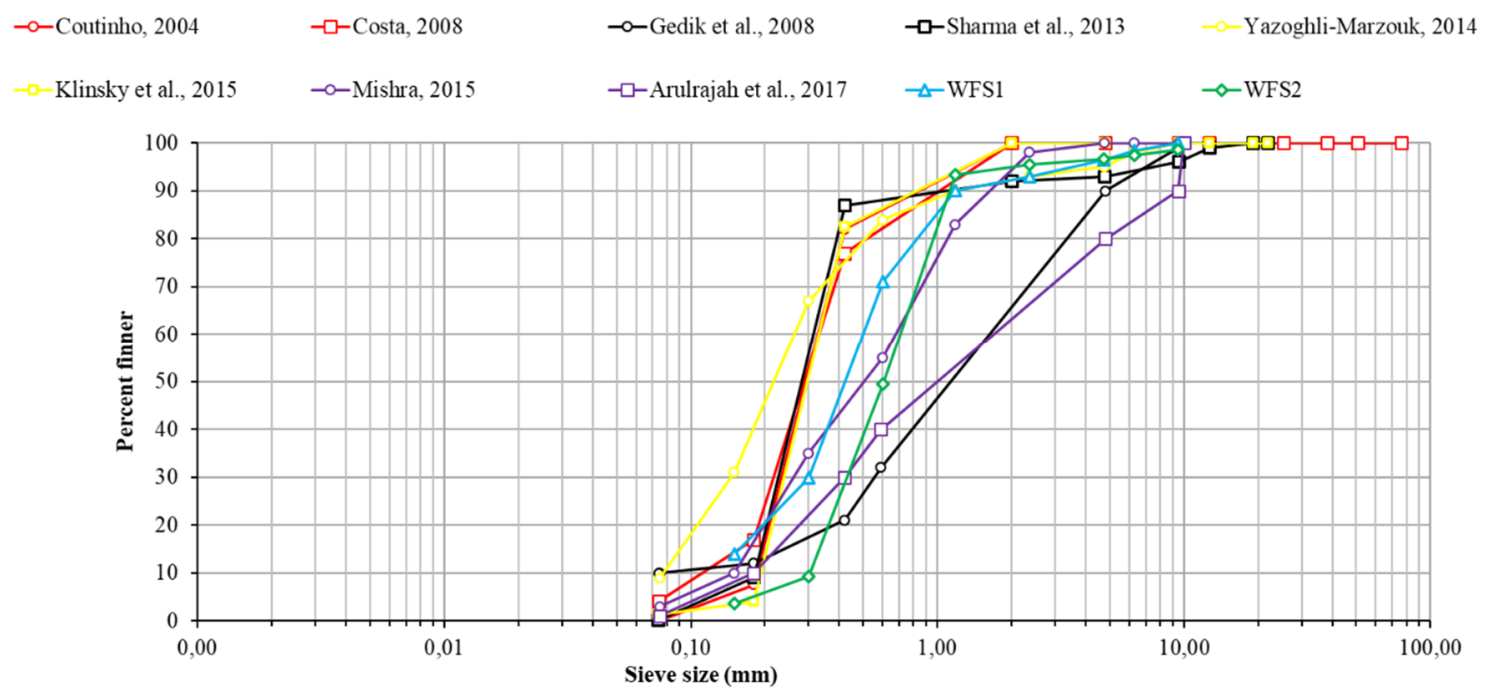

Figure 10. WFS particle size composition compared to other studies 
The WFS studied by Coutinho (2004), Costa (2008), Sharma et al. (2013), Yazoghli-Marzouk et al. (2014) and Klinsky et al. (2015) particularly, showed a particle size distribution similar to each other with a predominance of fine aggregates. However, these authors have searched for different uses for WFS in road projects, as commented in the previous paragraph.

The granulometric composition of WFS-1 and WFS-2 was closer to the results obtained by Mishra (2015), having an intermediate granulometric curve compared to the other results presented in Figure 10.

Arulrajah et al. (2017) and Gedik et al. (2008) worked with a WFS containing coarser particles aiming its use as a base course and asphalt wearing course (respectively).

These preliminary comparisons show the diversity of WFS uses in asphalt road projects in relation to a similar WFS composition, regardless of its origin and author. Regarding to the other physical properties of the waste, Table 5 presents physical properties of WFS according to the current literature (Mishra, 2015; Klinsky et al., 2015; Yazoghli-Marzouk et al., 2014; Abdulsattar, 2018). This table specifies the origin of the WFS (steelmakers or landfill) that each author used (identified by the label of the reference) and the asphalt course which the WFS was used; in addition, Table 6 presents the physical properties of each course in each study, according to the references presented in Table 5.

Table 5 - Physical characteristics of WFS according to other studies

\begin{tabular}{|c|c|c|c|c|c|c|}
\hline \multirow{2}{*}{ Properties } & \multicolumn{6}{|c|}{ Material/References } \\
\hline & WFS-1 & WFS-2 & [1] & {$[2]$} & [3] & [4] \\
\hline Unit weight $\left(\mathrm{Kg} / \mathrm{dm}^{3}\right)$ & 1429,6 & 1316,1 & 1600,0 & - & 2600,0 & 1937,1 \\
\hline Specific gravity $\left(\mathrm{g} / \mathrm{cm}^{3}\right)$ & 2,7 & 2,6 & 2,6 & 2,6 & 1,6 & 2,6 \\
\hline Sand equivalent (\%) & 37,6 & 49,3 & - & - & - & - \\
\hline Water absorption (\%) & 1,6 & 2,5 & 6,2 & - & - & - \\
\hline Materials finer than $75-\mu \mathrm{m}(\%)$ & 6,4 & 3,2 & 3,0 & - & - & - \\
\hline \multicolumn{7}{|c|}{ Reference label } \\
\hline References & \multicolumn{2}{|c|}{ Authors } & \multicolumn{2}{|l|}{ Use of WFS } & \multicolumn{2}{|c|}{ Origin of WF } \\
\hline [1] & \multicolumn{2}{|l|}{ Mishra, 2015} & \multicolumn{2}{|l|}{ Subgrade course } & \multicolumn{2}{|c|}{ Steelmakers } \\
\hline [2] & \multicolumn{2}{|c|}{ Klinsky et al., 2015} & \multicolumn{2}{|l|}{ Sub-base course } & \multicolumn{2}{|c|}{ Steelmakers } \\
\hline [3] & \multicolumn{2}{|c|}{ Yazoghli-Marzouk et al., 2014} & \multicolumn{2}{|l|}{ Base course } & \multicolumn{2}{|c|}{ Landfill } \\
\hline [4] & \multicolumn{2}{|c|}{ Abdulsattar, 2018} & \multicolumn{2}{|l|}{ HMA } & \multicolumn{2}{|c|}{ Steelmakers } \\
\hline
\end{tabular}

Table 6 - Main physical properties of asphaltic project course containing WFS

\begin{tabular}{cccccc}
\hline \multirow{2}{*}{ References } & \multicolumn{3}{c}{ Physical properties } & \multicolumn{2}{c}{ Criteria } \\
\cline { 2 - 6 } & CBR (\%) & TS (MPa) & ITS (MPa) & Values & Standard \\
\hline$[1]$ & 6,0 & - & - & $\geq 4,0$ & DNER ET DE-P00-001 \\
{$[2]$} & 55,0 & - & - & $\geq 30,0$ (Low Traffic) & DNER ET DE-P00-014 \\
{$[3]$} & - & 5,5 & - & $>90 \%$ of project TS & DNER ET DE-P00-004 \\
{$[4]$} & - & - & 0,6 & $>0,6$ & DNIT ES 031 \\
\hline
\end{tabular}

Table 6 shows the main physical properties of asphalt courses containing WFS within the criteria established by the standards. From this, the main conclusions are:

- According to Mishra (2015) clayey soils with the addition of 40\% of WFS are suitable for applications as a subgrade reinforcement course, since California Bearing Ratio (CBR) values were between 4 and $6 \%$ (soaked and unsoaked respectively), remaining within the limit established by Technical Specification DE-P00/001 of the Departamento Nacional de Estradas e Rodágem (DER). 
- Regarding the sub-base course, according to Klinsky et al. (2015), a CBR value of 55\% can be obtained in lateritic clayey soils mixed with 70\% of WFS (by weight), remaining within the specifications of the DER (DNER ET DE-P00-014, 2006) for low traffic.

- Yazoghli-Marzouk et al. (2014) showed that adding 6\% of Portland cement to WFS (100\% WFS by weight) can produce a suitable material for base courses.

- In HMA is suitable to replace $25 \%$ of virgin aggregates according to Abdulsattar (2018). Results of Indirect Tensile Strength (ITS) were about 0,6 MPa, which remains within the criteria specified by DNIT 031 (2006).

- Other researchers, such as Coutinho et al. (2004) and Costa (2008), also obtained good results with HMA containing WFS to satisfy standards. Likewise, Sharma et al. (2013), Gedik et al. (2008) and Arulrajah et al. (2017) incorporated WFS into reinforcement, sub-base and base courses, respectively.

- The studies cited here show that WFS could be reused as a subgrade, sub-base, base course, asphalt base layers and asphalt wearing courses and results support this technically. However, results from many characterization tests are not found, indicating that this subject is poorly studied.

- Moreover, the literature review shot that WFS from steelmakes are the most studied and there are no results from WFS landfills. Thus, WFS landfills researching is a challenge, since it is also an alternative material for asphalt road construction. Additionally, its reuse could give back areas for other uses, such as reforestation.

\section{CONCLUSION}

The results of the laboratory tests obtained in this study showed few differences between conventional aggregates and WFS. The physical and mechanical parameters remained within the criteria established by the major standards of mineral aggregates and road engineering. This behavior confirms that the WFS could be reused in asphalt road structures at different rates, as showed in other studies. The main benefits would be the reduction of construction costs, the reduction of the use of natural resources and the extension of the landfill's lifespan.

\section{ACKNOWLEDGEMENTS}

Thanks to CAPES and CNPq funding agencies for their assistance. To the laboratories of the Technological Institute of Era nautics, for the infrastructure for testing. And to Essencis Ecosystems for providing WFS.

\section{REFERENCES}

AASHTO (2001) T 304 Standard Method of Test for Uncompacted Void Content of Fine Aggregate. American Association of State Highway and Transportation Officials, Washington, D.C.

Abdulsattar, Z. A. (2018) Effect of waste foundry sand on indirect tensile strength of asphalt mixture. Journal of Engineering and Sustainable Development, v. 22, n. 4, p. 116-123. DOI: 10.13140/RG.2.2.13731.50727

ABIFA (2019) Associação brasileira de fundição: índices setoriais (2012-2019). Available at: <www.abifa.org.br>. (Access in: 11/01/2019).

ABNT (1987) NBR 6467 Agregados - Determinação do Inchamento em Agregados Miúdos. Associação Brasileira de Normas Técnicas. Rio de Janeiro.

ABNT (1992) NBR 12052 Solo ou Agregado Miúdo - Determinação do Equivalente de Areia - Método de Ensaio. Associação Brasileira de Normas Técnicas. Rio de Janeiro.

ABNT (2001) NBR NM 26 Agregados - Amostragem. Associação Brasileira de Normas Técnicas. Rio de Janeiro.

ABNT (2001a) NBR NM 27 Agregados - Redução de Amostras para Ensaios em Laboratório. Associação Brasileira de Normas Técnicas. Rio de Janeiro.

ABNT (2001b) NBR NM 30 Agregados - Determinação da Absorção de Água. Associação Brasileira de Normas Técnicas. Rio de Janeiro. 
ABNT (2003) NBR NM 248 Agregados - Determinação da Composição Granulométrica. Associação Brasileira de Normas Técnicas. Rio de Janeiro.

ABNT (2003b) NBR NM 46 Agregados - Determinação do Material Fino que Passa Através da Peneira 75 4 m, Por Lavagem. Associação Brasileira de Normas Técnicas. Rio de Janeiro.

ABNT (2003c) NBR NM 52 Agregado miúdo - Determinação da Massa Específica e Massa Específica Aparente. Associação Brasileira de Normas Técnicas. Rio de Janeiro.

ABNT (2004) NBR 10007 Amostragem de Resíduos Sólidos. Associação Brasileira de Normas Técnicas. Rio de Janeiro.

ABNT (2005) NBR 7211 - Agregados para Concreto - Especificações. Associação Brasileira de Normas Técnicas, Rio de Janeiro.

ABNT (2006) NBR NM 45 Agregados - Determinação da Massa Unitária e do Volume de Vazios. Associação Brasileira de Normas Técnicas. Rio de Janeiro.

Adegas, R. G. (2007) Perfil ambiental dos processos de fundição ferrosa que utilizam areias no Estado do Rio Grande do Sul. M.Sc. Thesis, Engenharia de Minas, Metalúrgica e Materiais, Universidade Federal do Rio Grande Sul, UFRGS, Porto Alegre.

Arulrajaha, A.; E. Yaghoubia; M. Imteaza and S. Horpibulsuka (2017) Recycled waste foundry sand as a sustainable subgrade fill and pipe-bedding construction material: Engineering and environmental evaluation. Sustainable Cities and Society, v. 28, n. 2017, p. 343-349. DOI: 10.1016/j.scs.2016.10.009

ASF-FIRST (2019) American Society of Foundry. Available at: <https://www.afsinc.org/afs-first>. (Access in: 08/07/2019).

ASTM (2005) C 123 Standard Test Methods for Lightweight Particles in Aggregate. American Society for Testing and Materials. West Conshohocken.

ASTM (2016) C 33 / C 33 M Standard Specification for Concrete Aggregates. American Society for Testing and Materials. American Society for Testing and Materials, West Conshohocken.

Bina, P. (2002) Metodologia de utilização de rejeitos industriais na pavimentação: estudo de caso de uso de areia de fundição. M.Lc. Thesis, Engenharia de Habitação, Instituto de Pesquisas Tecnológicas, São Paulo.

Bonet, I. I. (2002) Valorização do resíduo areia de fundição (RAF). M.Sc. Thesis, Engenharia de Produção, Universidade Federal de Santa Catarina, Florianópolis.

Cavalcanti, C.; A. Furtado; A. Stahel; A. Ribeiro; A. Mendes; C. Sekiguchi; D. Maimon; D. Posey; E. Pires; F. Brüseke; G. Rohde; G. Mammana; H. Leis; H Acselrad; J. Medeiros; J. L. D'Amato; M. L. Leonardi; M. Tolmasquim; O. Sevá Fo.; P. Stroh; P. Freire; P. May; R. Diniz and A. R. Magalhães (1994) Development and nature: Studies towards a sustainable society. INPSO/FUNDAJ, Institute for Social Research, Foundation Joaquim Nabuco, Ministry of Education, Federal Government, Recife.

Costa, C. (2008) Areia descartada de fundição em substituição ao agregado fino em misturas asfálticas para pavimentação. M.Sc. Thesis, Instituto Militar de Engenharia, Rio de Janeiro.

Coutinho B. and G. T. P. Fabbri (2004) Avaliação da reutilização da areia de fundição em misturas asfálticas densas do tipo CAUQ. Transportes, v. 12, n. 2, p. 50-57.

DER (2005) ET-DE-P00/001 Melhoria e Preparo do Subleito. Departamento Nacional de Infraestrutura de Transportes. Rio de Janeiro.

DER (2006) ET-DE-P00/004 Sub-Base ou Base de Solo-Cimento. Departamento Nacional de Infraestrutura de Transportes. Rio de Janeiro.

DER (2006) ET-DE-P00/014 Sub-Base ou Base Estabilizada Granulometricamente. Departamento Nacional de Infraestrutura de Transportes. Rio de Janeiro.

DNIT (2006) ES 031 Especificação de Serviço - Pavimentos Flexíveis - Concreto Asfáltico. Departamento Nacional de Infraestrutura de Transporte, Rio de Janeiro.

Dyer, P. P. O. L.; M. G. Lima; L. M. G. Klinsky; S. A. Silva and G. J. L. Coppio (2018) Environmental characterization of Foundry Waste Sand (WFS) in hot mix asphalt (HMA) mixtures. Journal of Construction and Building Materials, v. 171, p. 474-484. DOI: 10.1016/j.conbuildmat.2018.03.151

Gedik, A. G.; M. A. Lav and A. H. Lav (2008) Utilization of waste foundry sand as pavement sub-base and fill material. In: Ellis, Yu, McDowell, Dawson \& Thom (eds.) Advances in Transportation Geotechnics. Taylor \& Francis Group, London, ISBN 9780-415-47590-7, p. 143-147.

Klinsky, L. M. G.; V. S. S. Bardini; A. P. Furlan and G. T. P. Fabbri (2012) Reaproveitamento de areia de fundição residual em misturas de areia asfalto usinada a quente. Transportes, v. 20, n. 4, p. 27-34.

Klinsky, L. M. G.; V. S. S. Bardini; A. P. Furlan and G. T. P. Fabbri (2014) Efeito da adição de areia de fundição residual e cal a solos argilosos no módulo de resiliência. Transportes, v. 22, n. 2, p. 1-10.

Klinsky, L. M. G.; G. T. P. Fabbri and V. S. S. Bardini (2016) Reuse of Waste Foundry Sand Mixed with Lateritic Clayey Soils in Pavement Bases and Sub-bases Courses. In: 8th RILEM International Symposium on Testing and Characterization of Sustainable and Innovative Bituminous Materials, RILEM Bookseries, Springer, Dordrech, v. 11, p 569-582. DOI: 10.1007/97894-017-7342-3_46

Mishra, B. (2015) A study on characteristics of subgrade soil by use of foundry sand and iron turnings. International Journal of Science and Research (IJSR), v. 4, n. 12, p. 1262-1266.

Naik, T. R.; R. N. Kraus; B. W. Ramme and F. Canpolat (2012) Effects of fly ash and foundry and on performance of architectural precast concrete. Journal of Materials Civil Engineering, v. 24, n. 2012, p. 851-859. DOI: 10.1061/(ASCE)MT.19435533.0000432

São Paulo, O Estado (2007) Decisão de diretoria, no 152/2007/C/E, de 08 de agosto de 2007. Diário Oficial do Estado de São Paulo, Caderno Executivo I (Poder Executivo, Seção I), do dia 03 ago. 2008, pag. 51 (CETESB). 
Sharma, R. K. and A. Kumar (2013) Compaction and Sub-grade Characteristics of Clayey Soil Mixed with Foundry Sand and Fly Ash. International Journal of Engineering Research \& Technology (IJERT), v. 2, n. 10, p. 1504-1509.

TDC (1999) Beneficial re-use of foundry by-products-beneficial re-use for managers manual. The Casting Development Centre. Available at: <http://www.castingstechnology.com/public/services/environmenthealthandsafety/EHSBeneficialReuseofFoundryBy-products.asp>. (Access in: 04/26/2019).

Yazoghli-Marzouk, O.; N. Vulcano-greullet; L. Cantegrit; L. Friteyre and A. Jullien (2014) Recycling foundry sand in road construction-field assessment. Journal of Construction and Building Materials, v. 2014, n. 61, p. 69-78. DOI:

10.1016/j.conbuildmat.2014.02.055 